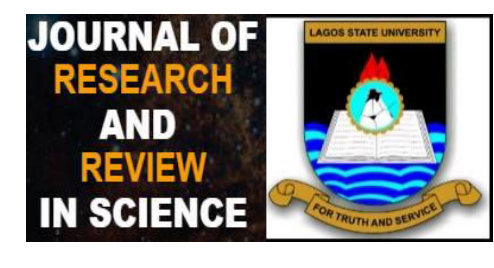

\title{
INVESTIGATION OF THE ANTIOXIDANT POTENTIAL AND TOXICITY OF THE WHOLE LEAF OF SOLANUM NIGRUM IN ALBINO RATS
}

Gbemisola Saibu ${ }^{1}$, Oluwatosin Benedict Adu ${ }^{1}$, Francis Faduyile ${ }^{2}$, Oluwadamilare lyapo ${ }^{3}$, Kayode Adekunle ${ }^{1}$, Abimbola Stella ${ }^{1}$, Sedoten Ogun ${ }^{1}$

${ }^{1}$ Department of Biochemistry, Faculty of Science, Lagos State University, Lagos, Nigeria

${ }^{2}$ Department of Pathology and Forensic Medicine, Lagos State University College of Medicine, Lagos, Nigeria

${ }^{3}$ Department Of Pathology, University College Hospital, Ibadan, Oyo, Nigeria

Correspondence

Gbemisola Morounke Saibu, Department of Biochemistry, Faculty of Science, Lagos State University, Lagos, Nigeria

Email: gbemisola.saibu@lasu.edu.ng

\section{Abstract:}

Introduction: Solanum nigrum is a common herb that grows wild and abundantly in open fields. Solanum nigrum has been shown to have antiinflammatory properties. Most animal studies have been on the aqueous and alcoholic extracts of Solanum nigrum leaf but this study focuses on the whole leaf of Solanum nigrum.

Aims: The aim of this study was to assess the antioxidant potential and effect of the whole leaf of S. nigrum on liver function parameters in rats.

Materials and Methods: Thirty male Wistar rats were divided into three groups of 10 rats each. Solanum nigrum leaves were air-dried, milled and administered orally to the rats at two doses $(100 \mathrm{mg} / \mathrm{kg}$ and $200 \mathrm{mg} / \mathrm{kg}$ body weight in $1 \%$ Carboxymethyl cellulose (CMC)) for seven days. The control group received $1 \mathrm{ml}$ of $1 \%$ CMC orally for seven days. On the eight day, animals were sacrificed and cardiac blood collected into plain bottles. Standard methods were used to determine serum nitric oxide, lipid peroxidation, gluthathione peroxidase, alanine aminotransferase, aspartate aminotransferase, alkaline phosphatase and total bilirubin. One gram portion of the organs (heart, kidney, liver and spleen) were fixed in formal saline for histopathological examination of 5 animals per group.

Results: Solanum nigrum had a Lethaal dose $\left(L_{50}\right)$ greater than $1000 \mathrm{mg} / \mathrm{kg}$ body weight without symptoms associated with toxicity. Nitric oxide concentration was significantly lower $(p<0.05)$ in the $S$. nigrum groups $(92.0-118.33 \mathrm{mM})$ compared to the control $(238.00 \mathrm{mM})$ whereas gluthathione peroxidase was significantly increased $(p<0.05)$ compared to the control group. The effects on these parameters were not dose dependent. There was no significant change in liver function parameters in all the groups. The histopathological screening of the control and test groups showed normal profile indicating no morphological alterations in the heart, liver, kidney and spleen of the rats.

Conclusion: These results indicate the antioxidant effect of Solanum nigrum whole leaf. It also showed that the consumption of $S$. nigrum leaves at the chosen doses had no adverse effect on the organs (Heart, Kidney, Liver, Spleen) of the rats. Further work will need to be done at higher doses, for longer duration and on both sexes of animals.

Keywords: Solanum nigrum, Antioxidant, Toxicology, Liver function test.

All co-authors agreed to have their names listed as authors.

This is an open access article under the terms of the Creative Commons Attribution License, which permits use, distribution and reproduction in any medium, provided the original work is properly cited.

(C) 2020 The Authors. Journal of Research and Reviews in Science - JRRS, A Publication of Lagos State University

JRRS

https:sciencejournal.lasucomputerscience.com 


\section{INTRODUCTION}

Free radicals are generated naturally as part of body metabolism. Smoking, radiation, drugs, pesticides, industrial solvents, pollutants from the environment are external factors that contribute to the production of free radicals. It is estimated that hydroxyl radical and its likes target a human cell every day and cause oxidative stress [1]. It is ironic that these vital elements (particularly oxygen) have harmful impact on the body through these reactive species [2]. The equilibrium between production and antioxidant neutralization of ROS is very sensitive, and if this equilibrium tends to overproduce reactive oxygen species (ROS), the cells begin to experience the effects of oxidative stress [3]. Protein, sugars, lipids, deoxyribonucleic acid (DNA) and ribonucleic acid molecules (RNA molecules) are the primary targets of reactive oxygen species (ROS), reactive nitrogen species (RNS) and reactive sulfur species (RSS) [4,5]. Antioxidants are substances that delay or prevent the oxidation of oxidizable cellular substrates by scavenging ROS, activating a protein battery or preventing ROS generation [6].

There are currently reported negative health effects of synthetic antioxidants such as butylated hydroxy anisole (BHA), butylated hydroxy toluene (BHT), and tertiary butylated hydroquinone and gallic acid esters [7]. Strong constraints have therefore been placed on their use causing a shift towards the use of natural antioxidants [7].

Fruits, vegetables and herbs are good sources of antioxidants [8]. However, many of these plants still need to be studied properly. Among them are the leaves of Solanum nigrum [9]. Solanum nigrum is a popular herb that grows wildly and abundantly in open spaces and was reported to grow in various continents such as North America [10, 11], Asia [12], Africa [13] and Europe [13]. It is popularly known as hierba mora [10], blacknight shade [11, 13], makoy [8], deadly nightshade [8] and efo odu [14]. Several works on Solanum nigrum have shown that it possesses antitumour [15], antiulcerogenic and ulcer healing [16], hepatoprotective [17, 18], cytoprotective [19], antioxidative [20, 21] and antimicrobial [22] activities.

While most animal studies have been on the aqueous and alcoholic extracts of dried Solanum nigrum leaf, this study focuses on the whole leaf since this is the form in which the plant is consumed. Special attention was also paid to the liver as a site of active metabolism because it is prone to toxicity $[23,24]$. This present study therefore aimed at assessing the antioxidant potentials and effect of the whole leaf of $S$. nigrum on liver function parameters in rats.

\section{MATERIAL AND METHODS}

\subsection{PREPARATION OF PLANT MATERIAL}

Fresh leaves of Solanum nigrum locally known as "Efo odu" by the Yoruba tribe were locally purchased at lyana-Iba Market, Lagos-badagry Expressway, Lagos. The plant materials were identified and authenticated at University of Lagos Herbarium, Lagos, Nigeria (LUH: 7945). The leaves were rinsed in distilled water, blended with a mechanical grinder and stored in the refrigerator all through the period of the study. The concentration of blended leaves in $1 \mathrm{ml}$ Carboxy methyl cellulose (CMC) was determined to be $140 \mathrm{mg}$ and this was used to determine the dosage.

\subsection{TOXICITY TESTS}

The acute toxicity value $\left(L_{50}\right)$ of Solanum nigrum whole leaf (SNWL) was determined according to the method of [25]. Six groups $(\mathrm{N}=10)$ male Wistar rats weighing $150-180 \mathrm{~g}$ were used in this experiment. Group-I received $1 \mathrm{ml}$ of $1 \% \mathrm{CMC}$ (control), Group- II, III, IV, V and VI received grounded leaves (50, 100, 200,500 and $1000 \mathrm{mg} / \mathrm{Kg}$ body weight) of Solanum nigrum in $1 \mathrm{ml}$ of CMC respectively. The rats were fed orally as a single dose using cannula. The animals were observed for $24 \mathrm{hrs}$ for signs of toxicity and the number of dead rat was recorded. Other signs of toxicity were also noted, such as excitation, tremors, twitches, motor coordination, reflex control and respiratory alterations which were used in the calculation of the acute toxicity value $\left(L_{50}\right)$.

\subsection{EXPERIMENTAL DESIGN}

Ninety (90) male Wistar rat purchased (60 rats for $L D_{50}$ test and 30 rats for the main experiments) from a local breeder was used in this experiment. The rats weighing $150-200 \mathrm{~g}$, were acclimatized under standard conditions for 4 weeks before induction. They were housed in plastic cages and fed with grower pellet and water ad libitum. Group feeding was done to ensure that animals in a group were subjected to the same condition. All the rats were fed with respective treatments, weighed weekly and cages were disinfected weekly. The rats were divided into three groups $(n=10)$. The animals were kept fasting overnight prior to each administration. SNWL was administered orally at two doses: Dose $1(100 \mathrm{mg} / \mathrm{kg})$ and Dose $2(200 \mathrm{mg} / \mathrm{kg}$ ) body weight in 1\% CMC and the control group received $1 \mathrm{ml}$ of $1 \%$ CMC orally for seven days.

\subsection{ANIMAL DISSECTION AND PRESERVATION OF COLLECTED SAMPLES}

The environment for dissection was disinfected with ethanol. The rats were anaesthetized using diethylether and laid on the board covered with aluminum foil. The rat was cut from the lower abdominal region up to the heart. Blood was collected by heart puncture and was allowed to clot before centrifugation at $1000 \mathrm{~g}$ for $10 \mathrm{~min}$ at $4{ }^{\circ} \mathrm{C}$ to separate 
serum. The serum was kept in freezer for the estimation of antioxidant and liver function parameters. A portion of the organs were fixed in formal saline for histopathological examination.

\subsection{ANTIOXIDANT ASSAY}

\subsubsection{NITRIC OXIDE ASSAY (NO)}

$125 \mu \mathrm{L}$ of $0.3 \mathrm{~N} \mathrm{NaOH}$ was added to $50 \mu \mathrm{L}$ of sample diluted with $75 \mu \mathrm{L}$ of distilled water and incubated at room temperature for $5 \mathrm{~min}$. $62.5 \mu \mathrm{L}$ of $10 \% \mathrm{ZnSO} 4$ was added to deproteinize and the resulting solution was centrifuged at $4000 \mathrm{rpm}$ for $30 \mathrm{~min}$. $200 \mu \mathrm{L}$ of the supernatant was then taken and added to $200 \mu \mathrm{L}$ of Griess reagent. Absorbance was read at 540nm after $30 \mathrm{~min}$ of incubation and nitrite concentration determined from the graph of absorbance against nitrite concentration [26].

\subsubsection{ENZYMATIC ASSAY OF GLUTATHIONE PEROXIDASE (GSH-PX)}

Solution containing $0.2 \mathrm{ml}$ of phosphate buffer $(0.4 \mathrm{M}$ $7.0 \mathrm{PH}), 0.1 \mathrm{ml}$ of sodium azide $(10 \mathrm{mM}), 0.2 \mathrm{ml}$ of reduced glutathione $(10 \mathrm{mM}), 0.1 \mathrm{ml}$ of $\mathrm{H}_{2} \mathrm{O}_{2}(0.2 \mathrm{mM})$ and $0.2 \mathrm{ml}$ of sample (enzyme) was incubated at $37^{\circ} \mathrm{C}$ for $10 \mathrm{~min}$. $0.2 \mathrm{ml}$ of $10 \%$ TCA was then added to terminate the reaction. $0.4 \mathrm{ml}$ of the supernatant was collected after centrifugation at 3000rpm for $15 \mathrm{mins}$ and added to $0.8 \mathrm{ml}$ thiol buffer and $20 \mu \mathrm{L}$ of freshly prepared 5,5'-dithio-bis-(2-nitrobenzoic acid) DTNB reagent. The absorbance within 5 mins of addition of DTNB at $412 \mathrm{~nm}$ was read against a blank containing $0.5 \mathrm{ml}$ of water instead of sample [27].

Calculation: The concentration of the $\mathrm{GSH}$ was calculated using molar extinction coefficient of DTNB $\left(14.15 \mathrm{mM}^{-1} \mathrm{~cm}^{-1}\right)$ as follows:

$\mathrm{mM} \mathrm{GSH}=$ Absorbance/14.15

\subsubsection{ESTIMATION OF LIPID PEROXIDATION}

$0.05 \mathrm{ml}$ of sample was reacted with $1.0 \mathrm{ml}$ of $1 \mathrm{x}$ thiobarbituric acid (TBA) reagent and incubated in boiling water bath for $15 \mathrm{~min}$. The tubes were immediately placed on ice and then centrifuged at $1000 \mathrm{rpm}$ for $10 \mathrm{~min}$. The absorbance of the clear supernatant against the blank was read at $535 \mathrm{~nm}$. The malondialdehyde concentration of the sample was calculated using an extinction coefficient $(\varepsilon)$ of $1.56 \times$ $105 \mathrm{M}^{-1} \mathrm{~cm}^{-1}$ [28]. Blank was prepared by replacing sample with distilled water.

Concentration $(\mathrm{MDA})=$ Absorbance

Extinction coefficient
(ALP) Assay and Total Bilirubin Assay. $0.1 \mathrm{ml}$ of sample (distilled water for blank), was treated with reagents according to manufacturer's instruction and absorbance measured.

\subsection{HISTOPATHOLOGICAL ANALYSIS}

All the Rats were sacrificed under diethyl ether anesthesia. The Stomach was quickly removed, rinsed in normal saline to remove excess blood. The organs were then placed in formal saline for routine histopathology analysis. Histopathology examination was carried out at Lagos State University Teaching Hospital (LASUTH) Department of Forensic Pathology.

\subsection{STATISTICAL ANALYSIS}

The statistical package for social science (SPSS) software version 17 was used for data analysis. Results were subjected to one way analysis of variance, Post Hoc test and Tukeys honesty significance test (Tukeys HSD).

\section{RESULTS AND DISCUSSION}

Solanum nigrum whole leaf acute toxicity level $\left(\mathrm{LD}_{50}\right)$ was not found to be within the concentration range of $50 \mathrm{mg} / \mathrm{kg}$ to $1000 \mathrm{mg} / \mathrm{kg}$ body weight used in this research, as there was no death or evidence of toxicity.

The effect of SNWL on the concentration of nitric oxide in the rat serum is shown in figure 1. Nitric oxide concentration was significantly $(P<0.05)$ decreased in groups treated with SNWL compared to control group.

Increased activity of glutathione peroxidase (figure 2) was seen in animals treated with SNWL but this increase was significant $(P<0.05)$ in group treated with $200 \mathrm{mg} / \mathrm{kg}$ SNWL compared to control group.

There was a reduction in lipid peroxidation (figure 3 ) in groups treated with SNWL but this reduction was not significant when compared to the control.

Table 1 shows the effect of SNWL on liver function parameters. There was no significant difference in treatment groups compared to control.

Figure 4, 5, 6 and 7 shows the histopathological profiles of the heart, kidney, liver and spleen respectively of rats for the various treatment groups. The control and test groups showed normal profiling indicating no morphological alterations.

\subsection{LIVER FUNCTION PARAMETERS}

Assay kits supplied by Randox Laboratories Ltd., United Kingdom was used in Alanine Aminotransferase (ALT) Assay, Aspartate Aminotransferase (AST) Assay, Alkaline Phosphatase 


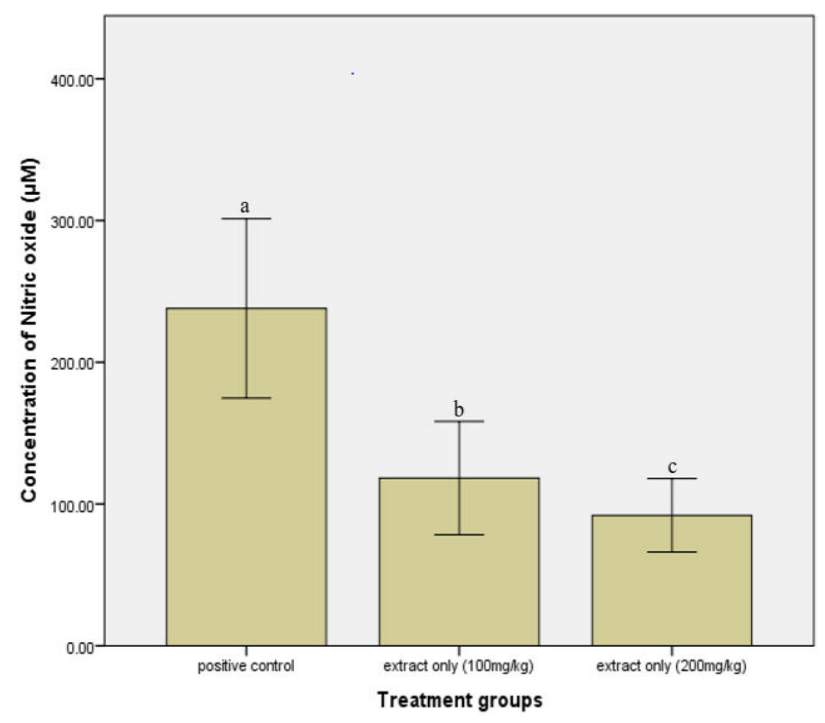

Fig. 1. The effect of blended leave of Solanum nigrum on the activity of glutathione peroxidase in the rat serum.

Data are presented as the mean \pm S.E.M from 10 rats. $B$ ars with different alphabets are significantly different at $p<0.05$

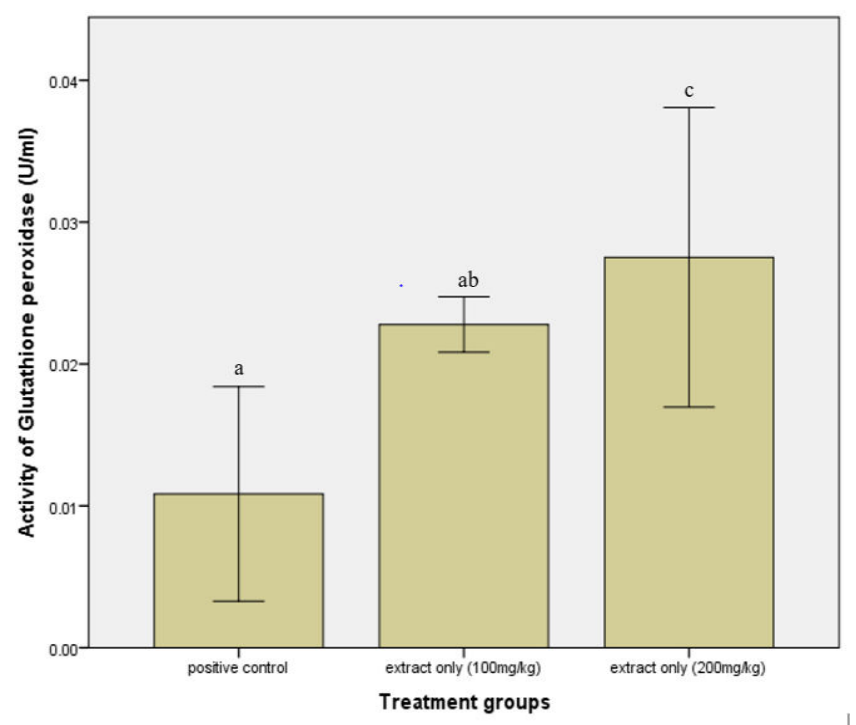

Fig. 2. The effect of blended leave of Solanum nigrum on the activity of glutathione peroxidase in the rat serum.

Data are presented as the mean \pm S.E.M from 10 rats. $B$ ars with different alphabets are significantly different at $p<0.05$.

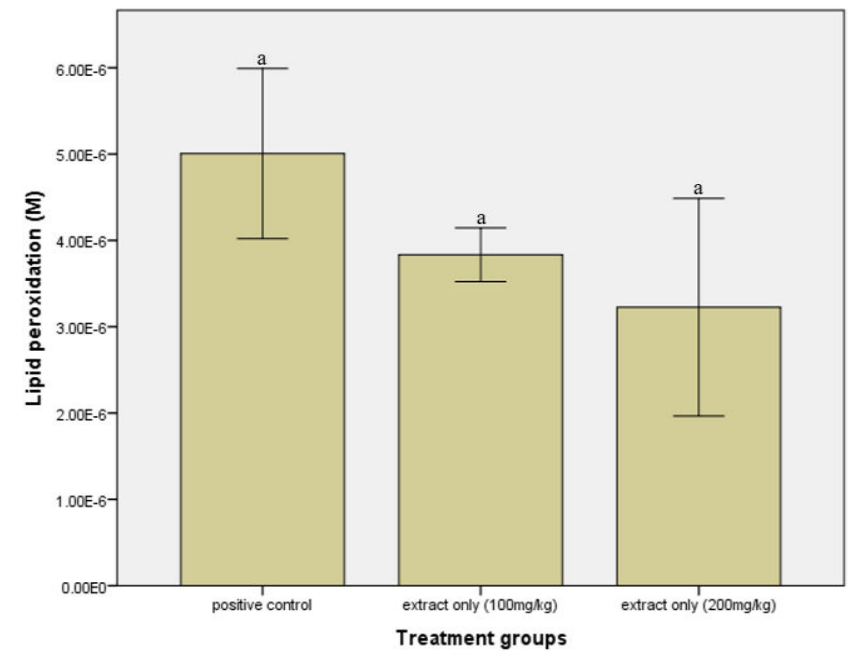

Fig. 3. The effect of blended leaves of Solanum nigrum on the concentration of lipid peroxidation in the rat serum.

Data are presented as the mean \pm S.E.M from 10 rats. Bars with different alphabets are significantly different at $p<0.05$.

Table 1. Effect of SNWL on Liver function parameters

\begin{tabular}{|c|c|c|c|}
\hline Treatment & $\begin{array}{c}\text { Control(CMC } \\
\text { only) }\end{array}$ & $\begin{array}{c}\text { Extract } \\
(100 \mathrm{mg} / \mathrm{kg})\end{array}$ & $\begin{array}{c}\text { Extract } \\
(200 \mathrm{mg} / \mathrm{kg})\end{array}$ \\
\hline $\begin{array}{c}\text { Serum } \\
\text { ALP activity } \\
(\mathrm{U} / \mathrm{I})\end{array}$ & $27.78 \pm 12.45^{a}$ & $47.84 \pm 9.35^{a}$ & $33.49 \pm 9.25^{a}$ \\
\hline $\begin{array}{c}\text { Serum } \\
\text { ALT activity } \\
(\mathrm{U} / \mathrm{I})\end{array}$ & $117.21 \pm 8.63^{\mathrm{a}}$ & $101.03 \pm 7.38$ & a $\begin{array}{l}103.88 \pm 13.72 \\
\text { a }\end{array}$ \\
\hline $\begin{array}{c}\text { Serum } \\
\text { AST activity } \\
(\mathrm{U} / \mathrm{I})\end{array}$ & $134.66 \pm 21.57^{\mathrm{a}}$ & $171.37 \pm 11.58^{a}$ & $\underset{a}{155.36 \pm 27.75}$ \\
\hline $\begin{array}{c}\text { Serum } \\
\text { bilirubin conc } \\
(\mathrm{mg} / \mathrm{dl})\end{array}$ & $0.946 \pm 0.62^{a}$ & $0.129 \pm 0.067^{\mathrm{a}}$ & $0.709 \pm 0.286^{a}$ \\
\hline Treatment & $\begin{array}{l}\text { Control(CMC } \\
\text { only) }\end{array}$ & $\begin{array}{l}\text { Extract } \\
(100 \mathrm{mg} / \mathrm{kg})\end{array}$ & $\begin{array}{l}\text { Extract } \\
(200 \mathrm{mg} / \mathrm{kg})\end{array}$ \\
\hline
\end{tabular}

${ }^{*}$ Data are presented as mean \pm S.E.M from 10 rats

${ }^{a b c} V$ Values with different superscript are significantly different.

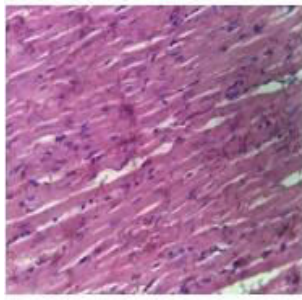

a

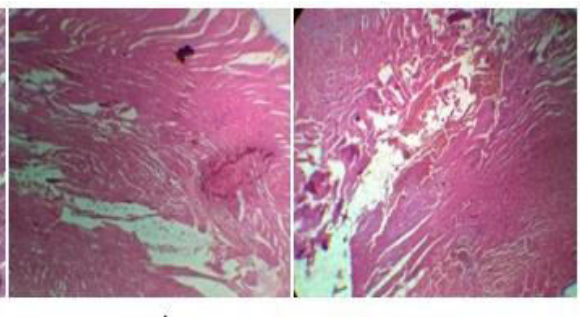

b

c
Fig. 4. Histopathological profiles of the heart of rats (magnification $\times 400$ )
a) Control group
b) Dose1
c) Dose 


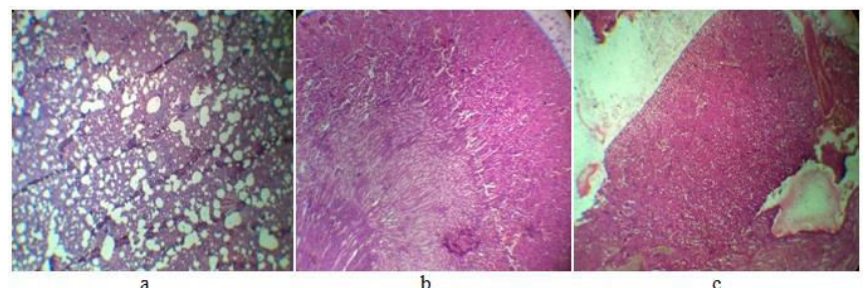

Fig. 5. Histopathological profiles of the kidney of rats (magnification $\times 400$ )

a) Control group

b) Dose1

c) Dose.

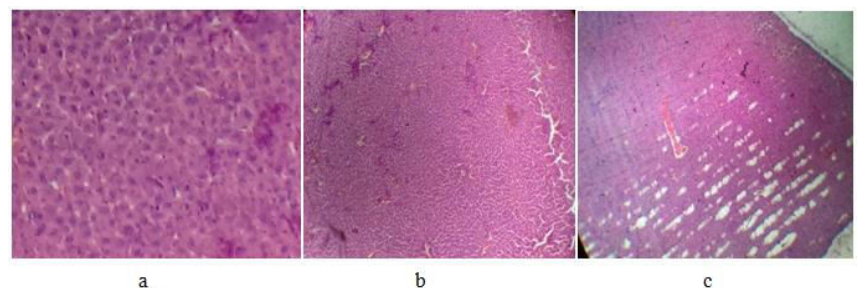

Fig. 6. Histopathological profiles of the liver of rats (magnification $\times 400$ )
a) Control group
b) Dose1
c) Dose 2
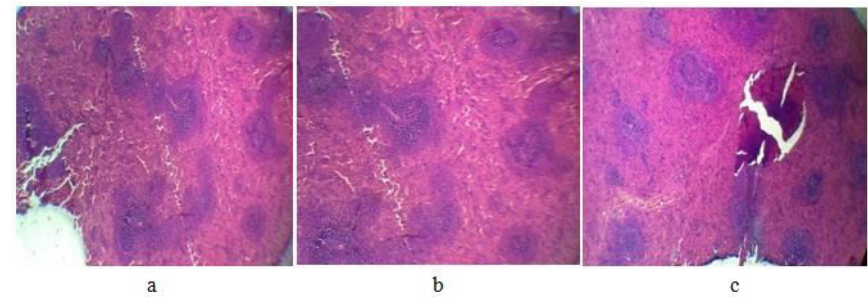

Fig. 7. Histopathological profiles of the spleen of rats (magnification $\times 400$ )

a) Control group

b) Dose1

c) Dose 2

\section{CONCLUSION}

Acute toxicity is described as the undesirable effect (such as functional defects in organs that may alter the functioning of the organism) which occurs either immediately or within 24 hours after a single or multiple administration of a substance [29]. The lethal dose $\left(L D_{50}\right)$ (the dose that kills 50 percent of the population of test animals) is used as a significant criterion in the estimation of acute toxicity and as a basic method for the general testing of toxicity of chemical and pharmacological agents [30]. There are controversies whether or not the leaves of Solanum nigrum is poisonous [31].The unripe fruit contains the highest concentration of toxins [32]. Raju et al. [33] worked on the extracts of the fruits of Solanum nigrum and arrived at an $L_{50}$ value of $2 \mathrm{~g} / \mathrm{kg}$ for the ethanol extract and $4 \mathrm{~g} / \mathrm{kg}$ body weight for the methanol extract. Rumiyati et al [34] also worked on the ethanolic extracts of the leaves of S. nigrum. They observed that treatment of animals with the highest dose $(1000 \mathrm{mg} / \mathrm{kg}$ body weight), did not cause the death of the animal groups. These findings are similar to that obtained in this study. No death might have been observed LASU Journal of Research and Review in Science because SNWL did not affect performance of the vital organs [34]. Findings from this study showed that the SNWL (50-1000 mg/kg body weight), did not cause the death of the animals. This implies that $S$. nigrum leaf is not toxic at the treatment doses.

Many scientific literatures have reported that the antioxidant properties of Solanum nigrum are effective to protect against diseases and degenerative processes caused by oxidative stress [38, 40-42]. Phytochemical studies revealed that Solanum nigrum contains polyphenolic compounds, mainly flavonoids and steroids; some of the other chemical constituents reported in leaves are riboflavin, nicotinic acid, vitamin C, $\beta$-carotene, citric acid, and oils [38]. The antioxidant property of Solanum nigrum leaves recorded in this study might be due to the presence of above mentioned constituents. Nitric oxide is often thought of as toxic. However, NO has also been found to reduce oxidative injury in several biological systems [35]. NO at low concentrations play a major role in inhibition of oxidative stress at both cellular and physiological levels [35]. In this study, the significant decrease $(p<0.05)$ in serum nitric oxide of the treated groups compared to the control clearly suggests that fresh leaves of Solanum nigrum have antioxidant effects. This result corroborate the finding of Shallan et al. [36] in which ethanolic extract of the fruits of Solanum nigrum scavenged Nitric oxide. Gluthathione peroxidase is a seleno-enzyme that catalyzes the reaction of hydroperoxides with reduced glutathione to form glutathione disulfide (GSSG) and the reduction product of hydroperoxide [37]. In this study, rats treated with higher dose $(200 \mathrm{mg} / \mathrm{kg})$ of Solanum nigrum whole leaf were observed to have shown significantly increased activities $(p<0.05)$ of glutathione peroxidase in the serum when compared to control rats. Rats treated with lower dose $(100 \mathrm{mg} / \mathrm{kg})$ of SNWL showed an increase in the activity of glutathione peroxidase however this increase was not significant compared to control. This suggests that SNWL is a more potent antioxidant at higher concentration. Solanum nigrum leaves may have served as a good antioxidant against free radicals thereby increasing the serum activities of glutathione peroxidase of treated groups compared with the reduced activity of gluthathione peroxidase in the control group. This also indicates that Solanum nigrum may be associated with decreased oxidative stress and free radical-mediated tissue damage. This is in agreement with the result of Zaidi et al [38] in which the treatment of rats both prior to or after stress with crude extract of dried leaves of Solanum nigrum and its active constituents resulted in a significant increase in the antioxidant enzymes activities and glutathione (GSH) level along with a decrease in lipid peroxidation (LPO). Lipid peroxidation is an autocatalytic process, which can cause tissue damage. When this process occurs in biological system, gross modification of structural, organizational and enzyme activity may occur [39]. In this study, it was observed that there was a reduction in lipid peroxidation amongst treatment groups however this change was not significant. This difference may have been significant 
$(P<0.05)$ if a higher concentration of Solanum nigrum leaves was used.

The activity and serum levels of various enzymes have been used to diagnose several disease conditions and assess plants for their safety. The elevated levels or activities of these enzymes in the serum indicate tissue or cellular damage [43]. Commonly assayed enzymes are the amino transferases. Alkaline phosphatase, aspartate aminotransferase and alanine aminotransferase showed no significant difference in their activity in the serum as compared to the control group at both treatment doses as shown in Table 1. These enzymes are localized within the cells of different organs. Since the leaves showed no significant effect on the activity of the enzymes, this indicates no increase in the synthesis of the enzyme, no organ dysfunction and subsequent leakage of these parameters into the serum. The activity of these three enzymes and total bilirubin concentration were usually used in liver function test to determine the functionality of the liver. The bilirubin concentration is usually increased in the serum in cases of toxicity from any foreign substances in the body. In this study, there was also no significant difference in concentration of the bilirubin between the treated rats and the control group. This shows that the leaves were properly metabolized by the liver and were not toxic at the concentrations used.

Histological examination which is also a standard for evaluating treatment related to pathological changes in tissues and organs of tested animals, showed no effect on the morphology of the liver, spleen, heart and kidney of the rats. The control and test groups showed normal profiling indicating no morphological alterations, and showing a correlation with the results of the liver function parameters.

\section{ACKNOWLEDGEMENTS}

A brief acknowledgement section may be given after the conclusion section just before the references. The acknowledgments of people who provided assistance in manuscript preparation, funding for research, etc. should be listed in this section. All sources of funding should be declared as an acknowledgement. Authors should declare the role of funding agency, if any, in the study design, collection, analysis and interpretation of data; in the writing of the manuscript. If the study sponsors had no such involvement, the authors should so state.

\section{COMPETING INTERESTS}

No competing

\section{REFERENCES}

1. Valko M, Izakovic M, Mazur M, Rhodes CJ, Telser J. Role of oxygen radicals in DNA damage and cancer incidence. Molecular and Cellular Biochemistry, 2004. 266(1-2): p. 37-56.
2. Lobo V, Patil A, Phatak A, Chandra N. Free radicals, antioxidants and functional foods: Impact on human health. Pharmacognosy Reviews, 2010. 4(8): p. 118.

3. Wiernsperger $\mathrm{N}$. Oxidative stress as a therapeutic target in diabetes: revisiting the controversy. Diabetes \& Metabolism, 2003. 29(6): p. 579-585.

4. Lü JM, Lin PH, Yao Q, and Chen C. Chemical and molecular mechanisms of antioxidants: experimental approaches and model systems. Journal of Cellular and Molecular Medicine, 2010. 14(4): p. 840-860.

5. Craft BD, Kerrihard AL, Amarowicz R, Pegg RB. Phenol-based antioxidants and the in vitro methods used for their assessment. Comprehensive Reviews in Food Science and Food Safety, 2012. 11(2): p. 148173.

6. Halliwell B, Gutteridge JM, Cross CE. Free radicals, antioxidants, and human disease: where are we now? The Journal of Laboratory and Clinical Medicine, 1992. 119(6): p. 598-620.

7. Branen A. Toxicology and biochemistry of butylated hydroxyanisole and butylated hydroxytoluene. Journal of the American Oil Chemists' Society, 1975. 52(2): p. 59.

8. Patel S, Gheewala N, Suthar A, Shah A. In-vitro cytotoxicity activity of Solanum nigrum extract against Hela cell line and Vero cell line. International Journal of Pharmacy and Pharmaceutical Sciences, 2009. 1(1): p. 38-46.

9. Akubugwo, I, Obasi A, Ginika S. Nutritional potential of the leaves and seeds of black nightshade-Solanum nigrum L. Var virginicum from Afikpo-Nigeria. Pakistan Journal of Nutrition, 2007. 6(4): p. 323-326.

10. Perez GR, Perez JL, Garcia LD, Sossa HM. Neuropharmacological activity of Solanum nigrum fruit. Journal of Ethnopharmacology, 1998. 62(1): p. 43-48.

11. Ogg Jr A, Rogers B, Schilling E. Characterization of black nightshade (Solanum nigrum) and related species in the United States. Weed Science, 1981: p. 27-32.

12. Villasenor IM, Lamadrid MRA. Comparative antihyperglycemic potentials of medicinal plants. Journal of Ethnopharmacology, 2006. 104(1-2): p. 129-131.

13. Atanu F, Ebiloma U, Ajayi E. A review of the pharmacological aspects of Solanum nigrum Linn. Biotechnology and Molecular Biology Reviews, 2011. 6(1): p. 1-8.

14. Idowu $O$. Contribution of neglected and underutilized crops to household food security and health among rural dwellers in Oyo State, Nigeria. International Symposium on Underutilized Plants for Food Security, Nutrition, Income and Sustainable Development 806. 2008.

15. Son YO, Kim J, Lim JC, Chung Y, Chung GH, Lee JC. Ripe fruits of Solanum nigrum $L$. inhibits cell growth and induces apoptosis in MCF-7 cells. Food and Chemical Toxicology, 2003. 41(10): p. 1421-1428. 
16. Jainu M, Devi CSS. Antiulcerogenic and ulcer healing effects of Solanum nigrum (L.) on experimental ulcer models: possible mechanism for the inhibition of acid formation. Journal of Ethnopharmacology, 2006. 104(1-2): p. 156-163.

17. Liu FP, Ma X, Li MM, Li Z, Han Q, Li R et al. Hepatoprotective effects of Solanum nigrum against ethanol-induced injury in primary hepatocytes and mice with analysis of glutathione S-transferase A1. Journal of the Chinese Medical Association, 2016. 79(2): p. 65-71.

18.Abdel-Rahim EA, Abdel-Mobdy YE, Ali RF, Mahmoud HA. Hepatoprotective effects of Solanum nigrum Linn fruits against cadmium chloride toxicity in albino rats. Biological Trace Element Research, 2014. 160(3): p. 400-408.

19.Kumar VP, Shashidhara S, Kumar M, Sridhara B. Cytoprotective role of Solanum nigrum against gentamicin-induced kidney cell (Vero cells) damage in vitro. Fitoterapia, 2001. 72(5): p. 481-486.

20.Abas, F, Lajis NH, Israf D, Khozirah S, Kalsom YU. Antioxidant and nitric oxide inhibition activities of selected Malay traditional vegetables. Food Chemistry, 2006. 95(4): p. 566-573.

21. Heo KS, Lim KT. Antioxidative effects of glycoprotein isolated from Solanum nigrum L. Journal of Medicinal Food, 2004. 7(3): p. 349-357.

22.Rani P, Khullar N. Antimicrobial evaluation of some medicinal plants for their anti-enteric potential against multi-drug resistant Salmonella typhi. Phytotherapy Research: An International Journal Devoted to Pharmacological and Toxicological Evaluation of Natural Product Derivatives, 2004. 18(8): p. 670-673.

23. Giboney PT. Mildly elevated liver transaminase levels in the asymptomatic patient. Am Fam Physician, 2005. 71(6): p. 1105-10.

24. Shen L, Fan JG, Shao Y, Zeng MD, Wang JR, Luo $\mathrm{GH}$, et al. Prevalence of nonalcoholic fatty liver among administrative officers in Shanghai: an epidemiological survey. World Journal of Gastroenterology: WJG, 2003. 9(5): p. 1106.

25. Turner R. Screening Methods in Pharmacology. 2013: Elsevier.

26. Yucel H, Ozaydin M, Dogan A, Erdogan D, Turker $\mathrm{Y}$, Ceyhan BM, et al. Plasma concentrations of asymmetric dimethylarginine, nitric oxide and homocysteine in patients with slow coronary flow. Scandinavian Journal of Clinical and Laboratory Investigation, 2012. 72(6): p. 495-500.

27.Flohé L, Günzler WA. Assays of glutathione peroxidase, in Methods in enzymology. 1984, Elsevier. p. 114-120.

28.Wills E. Lipid peroxide formation in microsomes. General considerations. Biochemical Journal, 1969. 113(2): p. 315-324.

29.Walum E. Acute oral toxicity. Environmental Health Perspectives, 1998. 106(suppl 2): p. 497-503.
30.Chinedu E, Arome D, Ameh FS. A new method for determining acute toxicity in animal models. Toxicology International, 2013. 20(3): p. 224.

31.Jimoh, F, Adedapo A, Afolayan A. Comparison of the nutritional value and biological activities of the acetone, methanol and water extracts of the leaves of Solanum nigrum and Leonotis leonorus. Food and Chemical Toxicology, 2010. 48(3): p. 964-971.

32.Frohne D, Pfänder J. A Colour Atlas of Poisonous Plants. Wolfe. , 1984( ISBN 0723408394.).

33.Raju K, Anbuganapathi G, Gokulakrishnan V, Rajkapoor B, Jayakar B, Manian S. Effect of Dried Fruits of Solanum nigrum LINN against CCI4-Induced Hepatic Damage in Rats. Biological and Pharmaceutical Bulletin, 2003. 26(11): p. 1618-1619.

34.Rumiyati R, Muna LN, Hidayati DN, Jenie RI. Acute toxicity and genotoxic activity of leunca (Solanum nigrum L.) herb ethanolic extract. Indonesian Journal of Cancer Chemoprevention, 2015. 6(1): p. 30-34.

35.Wink DA, Miranda KM, Espey MG, Pluta RM, Hewett SJ, Colton C, et al. Mechanisms of the antioxidant effects of nitric oxide. Antioxidants and Redox Signaling, 2001. 3(2): p. 203-213.

36.Shallan M, El-Baz G, Ali Hannaa F, Helmy Y. Antitoxidant effects against $\mathrm{CCl} 4$-induced liver damage of ripe fruit ethanolic extract of Black Nightshades. J Biol Chem Environ Sci, 2008. 3(4): p. 181-210.

37.Alam MN, Bristi NJ, Rafiquzzaman M. Review on in vivo and in vitro methods evaluation of antioxidant activity. Saudi Pharmaceutical Journal, 2013. 21(2): p. 143-152.

38.Zaidi SK, Hoda M, Tabrez S, Ansari SA, Jafri MA, Shahnawaz Khan $M$, et al. Protective effect of Solanum nigrum leaves extract on immobilization stress induced changes in rat's brain. Evidence-Based Complementary and Alternative Medicine, 2014. 2014.

39.Raghavan B, Kumari SK. Effect of Terminalia arjuna stem bark on antioxidant status in liver and kidney of alloxan diabetic rats. Indian Journal of Physiology and Pharmacology, 2006. 50(2): p. 133.

40.Arulmozhi V, Krishnaveni M, Karthishwaran K, Dhamodharan G, Mirunalini S. Antioxidant and antihyperlipidemic effect of Solanum nigrum fruit extract on the experimental model against chronic ethanol toxicity. Pharmacognosy Magazine, 2010. 6(21): p. 42.

41.Sen S, Chakraborty R, Sridhar C, Reddy Y, De B. Free radicals, antioxidants, diseases and phytomedicines: current status and future prospect. International Journal of Pharmaceutical Sciences Review and Research, 2010. 3(1): p. 91-100.

42.García-Nebot MJ, Recio I, Hernández-Ledesma B. Antioxidant activity and protective effects of peptide lunasin against oxidative stress in intestinal Caco-2 cells. Food and Chemical Toxicology, 2014. 65: p. 155-161. 
43.Raja M, Raja A, Imran M, Santha A, Devasena K.

Enzymes application in diagnostic prospects.

Biotechnology, 2011. 10(1): p. 51-59. 